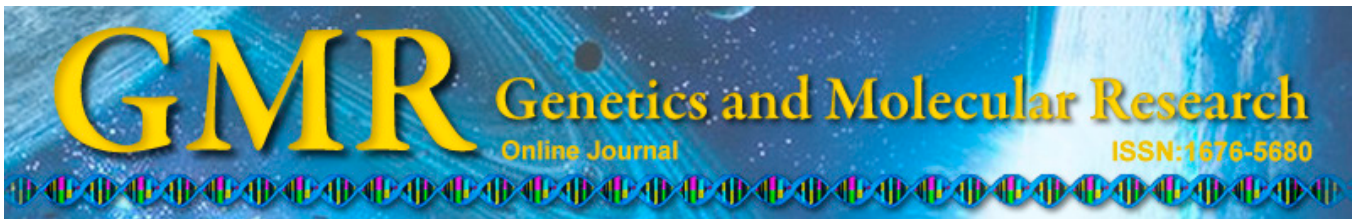

\title{
Isolation and characterization of novel microsatellite markers for molecular genetic diversity in Siganus fuscescens
}

\author{
Y.F. Ning ${ }^{1,2}$, Z.B. Li ${ }^{1,2}$, Q.H. Li ${ }^{1,2}$, G. Dai ${ }^{1,2}$, J.B. Shangguan ${ }^{1,2}$, Y. Yuan ${ }^{1,2}$ \\ and Y.S. Huang ${ }^{1,2}$ \\ ${ }^{1}$ Fisheries College, Jimei University, Xiamen, China \\ ${ }^{2}$ Fujian Provincial Key Laboratory of Marine Fishery Resources and \\ Eco-Environment, Xiamen, China \\ Corresponding author: Z.B. Li \\ E-mail: lizhongbao@jmu.edu.cn
}

Genet. Mol. Res. 14 (1): 89-92 (2015)

Received December 10, 2013

Accepted June 6, 2014

Published January 15, 2015

DOI http://dx.doi.org/10.4238/2015.January.15.11

\begin{abstract}
The rabbitfish Siganus fuscescens is an economically valuable species that is widely distributed throughout the estuaries, intertidal, and offshore coasts of the Indo-Pacific and eastern Mediterranean. Ten novel microsatellite loci from the genome of $S$. fuscescens were developed using the fast isolation protocol with amplified fragment length polymorphism of sequences containing repeats. Polymorphisms in these 10 microsatellite markers were determined from 32 wild individuals. The number of alleles per locus and the polymorphism information content ranged from 2 to 5 and from 0.059 to 0.668 , respectively. The observed and expected heterozygosities varied from 0.063 to 0.781 and from 0.062 to 0.731 , respectively. Although 1 locus (LZY-X7, P < 0.005) showed significant deviation from the Hardy-Weinberg equilibrium, no deviations were detected in the other 9 loci. These microsatellite loci may be useful for further population genetic studies, conservation studies, population structure assessment, and linkage map construction of S. fuscescens.
\end{abstract}

Key words: Genetic markers; Microsatellite; Siganus fuscescens; Fragment length polymorphism of sequences containing repeats 


\section{INTRODUCTION}

The rabbitfish Siganus fuscescens belongs to the order Perciformes, family Siganidae, which is widely distributed throughout the estuaries, intertidal, and offshore coasts of the Indo-Pacific and eastern Mediterranean. In China, this species is mainly distributed in the southeastern coastal area. As an omnivorous habit fish, its fingerlings feed mainly on benthic algae and organic detritus (Yang et al., 2000). It is becoming increasingly sought after not only because of its high protein content and good taste but also because it plays an important role in the ecological purification of the aquaculture water quality (Ma and Liu, 2006). However, increasing evidence suggests that overfishing, high exploitation, and habit destruction have sharply decreased the population of this species (Jumawan-Nanual and Metilla, 2008). Currently, the study of population dynamics, genetic diversity, and conservation of this economically valuable species is insufficient and limited, making the development of genetic markers in S. fuscescens urgent and necessary. Microsatellite simple sequence repeats, because of their extensive applications and advantages in the study of population genetics, population differentiation, linkage analysis, and evolutionary studies, are considered to be powerful tools for researching species genetic conservation (Wang et al., 1994). In this study, we identified 10 novel microsatellite markers in S. fuscescens with the goal of protecting this natural resource.

\section{MATERIAL AND METHODS}

Genetic DNA was sampled from the muscle tissues from a wild S. fuscescens individual captured in Xiamen, China, by using the Genomic DNA Extraction kit (Tiangen, Beijing, China). The microsatellite-enriched library was derived from a single $S$. fuscescens using fast isolation by amplified fragment length polymorphism (AFLP) of sequences containing repeats (FIASCO) protocol (Zane et al., 2002) using 2 biotinylated probes $\left[(\mathrm{GT})_{15}\right.$ and $\left.(\mathrm{CT})_{15}\right]$ (Cao et al., 2012). A total volume of $2000 \mu \mathrm{g}(100 \mu \mathrm{g} / \mu \mathrm{L})$ DNA was digested by the restriction enzyme FastDigestTrulI at $37^{\circ} \mathrm{C}$ for $5 \mathrm{~min}$. The enzyme was inactivated by heating for $5 \mathrm{~min}$ at $65^{\circ} \mathrm{C}$. Digested fragments approximately $400-1200 \mathrm{bp}$ in size were then ligated to the MseI adapter 1 (5'-ACGATGAGTCCTGAG-3')/MseI adapter 2 (5'-TACTCAGGACTCAT-3') by T4 DNA ligase (Fermentas, Vilnius, Lithuania) overnight at $22^{\circ} \mathrm{C}$. The linker-ligated mixture was denatured at $95^{\circ} \mathrm{C}$ for $10 \mathrm{~min}$ and then hybridized to the biotin-labeled oligonucleotide probes $(\mathrm{CT})_{15}$ and $(\mathrm{GT})_{15}$ at $61^{\circ} \mathrm{C}$ for $1 \mathrm{~h}$. Microsatellite-containing fragments were captured via streptavidin-coated magnetic sphere particles (Promega, Madison, WI, USA). Target DNA fragments were released from the beads after washing and were re-amplified using MseI adapter 1. After purification by GenCleanPCR (Generay, Shanghai, China), the products were ligated into the PMD19-T vector (Takara, Shiga, Japan) at $16^{\circ} \mathrm{C}$ for $3.5 \mathrm{~h}$ and transformed into OneShot chemically competent Escherichia coli (Invitrogen, Carlsbad, CA, USA) grown overnight at $37^{\circ} \mathrm{C}$. Transformants were cultured on Luria-Bertani agar plates supplemented with $60 \mu \mathrm{g} / \mathrm{mL}$ ampicillin. After polymerase chain reaction (PCR) amplification of positive colonies via using M13 universal primers, the sizes of inserted products were determined using 1\% agarose gel electrophoresis. A total of 128 positive clones with DNA fragments bands of 500-1200 bp were sequenced by the Majorbio Company (Shanghai, China), 117 of which contained microsatellites according to the SSRhunter1.3 software, while 40 pairs of microsatellite amplification primers were designed by the Primer Premier version 5.0 software. 
After optimizing the amplification conditions for each primer pair in an Eppendorf Mastercycler Gradient System (Eppendorf, Hamburg, Germany), 34 primer pairs were successfully selected for testing by amplifying genomic DNA of 32 wild S. fuscescens individuals collected from Xiamen, China. PCR was carried out in a $10-\mu \mathrm{L}$ volume consisting of $50 \mathrm{ng}$ genomic DNA, 10X Taq buffer, $2 \mathrm{mM} \mathrm{MgCl}, 0.4 \mu \mathrm{M}$ of each primer, $0.2 \mathrm{mM}$ of each dNTP, and $0.25 \mathrm{U} \mathrm{Taq}$ DNA polymerase (Fermentas). The reaction protocol was as follows: predenature at $94^{\circ} \mathrm{C}$ for $5 \mathrm{~min}$, followed by 32 cycles of denaturation at $94^{\circ} \mathrm{C}$ for $30 \mathrm{~s}$, annealing at the optimal temperature (Table 1) for $30 \mathrm{~s}$, and $72^{\circ} \mathrm{C}$ for $1 \mathrm{~min}$, with a final 10 -min elongation step at $72{ }^{\circ} \mathrm{C}$. The PCR products were resolved on $6 \%$ denaturing polyacrylamide gels in a Sequi-Gen Sequencing Cell (Bio-Rad, Hercules, CA, USA) and visualized by silver staining. A 10-bp DNA ladder (Fermentas) was used to identify the alleles. The number of alleles per locus, the observed and expected heterozygosities, tests for linkage disequilibrium (LD), and Hardy-Weinberg equilibrium (HWE) were obtained using the POPGEN 32 (version 1.32) software (Yeh et al., 2000). Polymorphic information content was calculated using CERVUS 3.0 (version 3.0).

\section{RESULTS AND DISCUSSION}

Error analysis was carried out using MICRO-CHECKER (Van Oosterhaut et al., 2004). Nine loci were in HWE ( $P>0.005$ ) except locus (LZY-X7), which significantly deviated from the HWE after Bonferroni's correction $(\mathrm{P}<0.005$; Table 1). Characterization of the loci is presented in Table 1. Ten loci were shown to be polymorphic with 2-5 alleles and polymorphism information content ranged from 0.059 to 0.668 . The observed and expected heterozygosities ranged from 0.063 to 0.781 and from 0.062 to 0.731 , respectively.

\begin{tabular}{|c|c|c|c|c|c|c|c|c|c|}
\hline $\begin{array}{l}\text { GenBank } \\
\text { accession No. }\end{array}$ & Locus ID & Primer sequences $\left(5^{\prime}-3^{\prime}\right)$ & Repeat motif & $\begin{array}{c}\mathrm{Ta} \\
\left({ }^{\circ} \mathrm{C}\right)\end{array}$ & $N_{\mathrm{A}}$ & $\begin{array}{l}\text { Allele size } \\
\quad \text { (bp) }\end{array}$ & $\mathrm{PIC}$ & $H_{\mathrm{O}}$ & $H_{\mathrm{E}}$ \\
\hline KF773749 & LZY-14 & $\begin{array}{l}\text { F: ATCACTGGTGGAATGTTGT } \\
\text { R: TCCTCTGCTCCTTTGTCT }\end{array}$ & $(\mathrm{GT})_{14}(\mathrm{GTGC})_{3}(\mathrm{GT})_{7}$ & 55 & 5 & $149-187$ & 0.601 & 0.781 & 0.659 \\
\hline KF773750 & LZY-39 & $\begin{array}{l}\text { F: TGTTGGTAATCGCTCTG } \\
\text { R: GATGGAAGACACGGATG }\end{array}$ & $(\mathrm{GT})_{33}$ & 42 & 5 & $126-144$ & 0.539 & 0.500 & 0.594 \\
\hline KF773751 & LZY-36 & $\begin{array}{l}\text { F: GAGCGAGGACCACAAACA } \\
\text { R: TCCCACCCTACCACCAC }\end{array}$ & $(\mathrm{AG})_{27}$ & 58 & 3 & $109-117$ & 0.444 & 0.469 & 0.510 \\
\hline KF773752 & LZY-7 & $\begin{array}{l}\text { F: TTACAATCTTCCTGGCTCTG } \\
\text { R: GGGCTCACCCACTTCTG }\end{array}$ & $(\mathrm{TCC})_{10}$ & 55 & 5 & $195-223$ & 0.598 & 0.688 & 0.669 \\
\hline KF773753 & LZY-X7 & $\begin{array}{l}\text { F: CTGGTTGTGCGATCCCTG } \\
\text { R: CCCTTCCTGACATACCCTCC }\end{array}$ & $(\mathrm{GT})_{8}$ & 53 & 5 & $260-290$ & $0.659^{*}$ & 0.219 & 0.720 \\
\hline KF773754 & LZY-50 & $\begin{array}{l}\text { F: GCCTTTGGTATCCGTCTG } \\
\text { R: TGCGTCGCCTCACTTTT }\end{array}$ & $(\mathrm{AG})_{7} \mathrm{AC}(\mathrm{AG})_{23}(\mathrm{TG})_{13}$ & 50 & 5 & $170-195$ & 0.668 & 0.719 & 0.731 \\
\hline KF773755 & LZY-71 & $\begin{array}{l}\text { F: TAAGGGTTTGTTAGAGTGT } \\
\text { R: GGGGCTGTATTATTGTC }\end{array}$ & $(\mathrm{GT})_{19}(\mathrm{GA})_{6}$ & 48 & 2 & $251-260$ & 0.195 & 0.250 & 0.222 \\
\hline KF773756 & LZY-43 & $\begin{array}{l}\text { F: GTCAGTGTTAGTAGAGCAAGT } \\
\text { R: CAGATAAATCACCAGGAA }\end{array}$ & $(\mathrm{AAGTC})_{4}$ & 45 & 4 & $190-220$ & 0.491 & 0.688 & 0.559 \\
\hline KF773757 & LZY-61 & $\begin{array}{l}\text { F: CGACCAGCACAGGATAG } \\
\text { R: CCATGTTGTCATAGGGAG }\end{array}$ & $(\mathrm{TG})_{16}$ & 42 & 2 & $115-120$ & 0.305 & 0.250 & 0.381 \\
\hline KF773758 & LZY-19 & $\begin{array}{l}\text { F: AGGGCTGAAGACGTAGAT } \\
\text { R: AAAGGACAGTGGAAATGG }\end{array}$ & $(\mathrm{AG})_{7} \mathrm{~T}(\mathrm{GA})_{33}$ & 42 & 2 & $230-240$ & 0.059 & 0.063 & 0.062 \\
\hline
\end{tabular}

$\overline{\mathrm{Ta}}=$ annealing temperature; $N_{\mathrm{A}}=$ number of polymorphic alleles per locus; PIC $=$ polymorphism information content; $H_{\mathrm{O}}=$ observed heterozygosity; $H_{\mathrm{E}}=$ expected heterozygosity. ${ }^{*}$ Indicates significant departure $(\mathrm{P}<0.005)$ from expected Hardy-Weinberg equilibrium conditions after correction for multiple tests $(\mathrm{k}=10)$. 
The 10 novel polymorphic microsatellite loci presented may be useful for further population genetic studies, conservation studies, population structure assessment, and linkage map construction of $S$. fuscescens.

\section{ACKNOWLEDGMENTS}

Research supported by the National Natural Science Foundation of China (\#31272668), the Returned Scholars Project of the Ministry of Education of China [(2006)331], the Foundation for Innovative Research Team of Jimei University, China (\#2010A004), and the Program for New Century Excellent Talents in Fujian Province University [(2006)35].

\section{REFERENCES}

Cao YY, Li ZB, Li QH, Dai G, et al. (2012). Development and characterization of microsatellite loci for Fenneropenaeus penicillatus Alcock. Afr. J. Biotechnol. 11: 10831-10833.

Jumawan-Nanual B and Metilla EB (2008). Population structure and reproductive biology of Siganus fuscescens Houttuyn 1782 (Perciformes, Siganidae) in Pujada Bay, Southeastern Mindanao, Philippines. Philipp. Scient. 45: 62-79.

Ma Q and Liu J (2006). Introduction and prospect of the systematics study of Siganidae in China. South China Fish. Sci. 4: 68-74.

Van Oosterhaut C, Hutchinson WF and Shipley P (2004). MICRO-CHECKER: software for identifying and correcting genotyping errors in microsatellite data. Mol. Ecol. Notes 4: 535-538.

Wang Z, Weber JL, Zhong G and Tanksley SD (1994). Survey of plant short tandem DNA repeats. Theor. Appl. Genet. 1: $1-6$.

Yang SY, Chen MR, Wang L, Cao WQ, et al. (2000). The role of Siganus fuscescens in the shrimp ponds ecosystem. In: 2000 Conference on Environment Science of Shellfish and Marine Ecology (CSOL 2000), Xiamen, 57.

Yeh FC, Yang R, Boyle TJ, Ye Z, et al. (2000). PopGene32, Microsoft Windows-based freeware for population genetics analysis. Version 1.32, Molecular Biology and Biotechnology Centre University of Alberta, Alberta.

Zane L, Bargelloni L and Patarnello T (2002). Strategies for microsatellite isolation: a review. Mol. Ecol. 11: 1-16. 